\title{
Effects of salinity and nitrogen on cotton growth in arid environment
}

\author{
Weiping Chen • Zhenan Hou • Laosheng Wu • \\ Yongchao Liang • Changzhou Wei
}

Received: 23 October 2008 / Accepted: 19 December 2008/Published online: 21 January 2009

(C) The Author(s) 2009. This article is published with open access at Springerlink.com

\begin{abstract}
The influences of different $\mathrm{N}$ fertilization rates and soil salinity levels on the growth and nitrogen uptake of cotton was evaluated with a pot experiment under greenhouse conditions. Results showed that cotton growth measured as plant height was significantly affected by the soil salinity and Nsalinity interaction, but not by $\mathrm{N}$ alone. Cotton was more sensitive to salinity during the emergence and early growth stages than the later developmental stages. At low to moderate soil salinity, the growth inhibition could be alleviated by fertilizer application. Soil salinity was a dominated factor affecting cotton's above-ground dry mass and root development. Dry mass of seed was reduced by $22 \%, 52 \%$, and $84 \%$ respectively, when the soil salinity level increased
\end{abstract}

Responsible editor: Timothy J. Flowers.

W. Chen

State Key Lab of Urban and Regional Ecology,

Research Center for Eco-Environmental Sciences,

Chinese Academy of Sciences,

Beijing 100085, China

Z. Hou $(\bowtie) \cdot$ Y. Liang $\cdot$ C. Wei

Department of Resources and Environmental Sciences,

Shihezi University,

Shihezi Xinjiang 832003, China

e-mail: hzatyl@163.com

W. Chen $\cdot$ L. Wu

Department of Environmental Sciences,

University of California,

Riverside, CA 92521, USA from control level of $2.4 \mathrm{dS} \mathrm{m}^{-1}$ to $7.7 \mathrm{dS} \mathrm{m} \mathrm{m}^{-1}$, $12.5 \mathrm{dS} \mathrm{m}^{-1}$ and to $17.1 \mathrm{dS} \mathrm{m}^{-1}$, respectively. $\mathrm{N}$ uptake increased with $\mathrm{N}$ fertilization at adequate rates at both low and medium soil salinities but was not influenced by over $\mathrm{N}$ fertilization. At higher salinities, $\mathrm{N}$ uptake was independent of $\mathrm{N}$ rates and mainly influenced by soil salinity. The uptake of $\mathrm{K}$ decreased with soil salinity. The concentration of $\mathrm{Na}, \mathrm{Cl}$ and $\mathrm{Ca}$ in plant tissues increased with soil salinity with highest concentrations in the cotton leaf.

Keywords Soil salinity $\cdot$ Nitrogen $\cdot$ Fertigation . Cotton

\section{Introduction}

Soil salinity adversely affects crop productivity and agricultural sustainability in many areas of the world, especially in arid and semi-arid regions (Mohammed et al. 1998; Feng et al. 2005; Endris and Mohammed 2007). Plant growth can be inhibited by high salt concentrations through osmotic stress, nutritional imbalance, and specific ion toxicity (Alam 1994; Jacoby 1994; Munns and Tester 2008). It is known that the growth inhibition and the adverse effects induced by salinity can be alleviated by proper use of fertilizer and water management, depending on plant species, salinity level, and environmental conditions (Shen et al. 1994; Soliman et al. 1994; Albassam 2001; Flores et al. 2001; Tuna et al. 2007). Nonetheless, over 
fertilization with $\mathrm{N}$ may contribute to soil salinization and increase the negative effects of soil salinity on plant performance (Villa-Castorena et al. 2003). In addition, the potential for $\mathrm{NO}_{3}$ leaching may increase where moderate to high amounts of salts are present in the soils because plants under salt stress can not absorb and or utilize the applied $\mathrm{N}$ as efficiently as the plants not subjected to salt stress (Ward et al. 1986; Pessarakli and Tucker 1988; Bowman et al. 2006). Further, as the salinity of irrigation water rises, the leaching fraction must increase to control root zone salinity. Higher leaching fractions combined with lower $\mathrm{N}$ use efficiencies represent a worst case with regard to groundwater pollution (Devitt and Morris 1990; Leskys et al. 1999). Therefore, judicious fertilizer and water management is essential in salt-affected soils to sustain yields and to minimize the degradation of soil and groundwater.

In the arid Xinjiang province of China, cotton is being grown widely because of its high salinity tolerance. In these regions, water sources are frequently brackish and high-quality water for agricultural purposes is increasingly scarce due to rising demands from urban areas (Wang et al. 2008). As a result, the proportion of crop production under deficit irrigation with poorer quality water is increasing. Drip irrigation is thought to be the most efficient irrigation method (Mohammad 2004). With fertigation (combined irrigation and fertilization), the application of fertilizer can be controlled to match the plant needs at each physiological growth stage, which can enhance plant growth and increase fertilizer and water use efficiency while minimizing environmental pollution.

Plant responses to salinity change with plant age, plant development, and growth stages (Maas 1993). It is important to study plant growth response to $\mathrm{N}$ and soil salinity during the whole plant life cycle to reveal whether the amount of $\mathrm{N}$ applied alleviates or aggravates the detrimental effects of salinity during a specific growth stages (Villa-Castorena et al. 2003). In addition, examining plant growth during the whole growing season provides information about crop salt tolerance over time. The objective of this work was to determine the influence of different soil salinity levels and $\mathrm{N}$ fertilization rates on the cotton growth, including the root development, plant height, and above-ground mass. The uptake of $\mathrm{N}, \mathrm{K}, \mathrm{Ca}, \mathrm{Na}$ and $\mathrm{Cl}$ were measured to understand the combined effects of $\mathrm{N}$ and salinity on cotton growth.

\section{Materials and methods}

\section{Experimental design}

The experiments were conducted in a greenhouse from May to November at an agricultural experimental station at Shihezi University, Xinjiang, China $\left(86^{\circ} 02^{\prime} \mathrm{E}, 44^{\circ} 18^{\prime} \mathrm{N}\right)$. Cotton (Gossypium hirsutum L. cv. Xinluzao 13) was grown in plastic pots (height $0.55 \mathrm{~m}$, top diameter $0.48 \mathrm{~m}$, bottom diameter $0.40 \mathrm{~m}$ ) with a volume of $84 \mathrm{~L}$. The minimum and maximum air temperature was $17^{\circ} \mathrm{C}$ and $32^{\circ} \mathrm{C}$, respectively. The relative humidity ranged from 40 $62 \%$. A clay loam soil taken from the station field was passed through a $2-\mathrm{mm}$ sieve and packed in the plastic pots with $0.1 \mathrm{~m}$ increments to $0.5 \mathrm{~m}$. Each pot was filled with $96 \mathrm{~kg}$ air dry soil. The bulk density of the packed soil was $1.2 \mathrm{~g} \mathrm{~cm}^{-3}$ and the gravimetric water content of the saturated paste of the soil was $45.6 \%$. Selected physical and chemical properties of the soil are presented in Table 1.

The experimental design was a $4 \times 4$ factorial with four salinity treatments and four levels of nitrogen. Soil salinity was created with applying $\mathrm{NaCl}$ and $\mathrm{CaCl}_{2}$ (1:1 weight ratio) to the soil before the experiment. The resulting ion compositions in the treated soil were similar to those observed in the local saline soils. The soil salinity levels $\left(\mathrm{EC}_{\mathrm{e}}\right.$, electrical conductivity of a saturated-paste extract) were 2.4, 7.7, 12.5, and $17.1 \mathrm{dS} \mathrm{m}^{-1}$, referred to as non-saline (S0), low (SL), medium (SM), and high (SH) saline, respectively. The low and high salt treatments were set based on the $100 \%$ and $50 \%$ yield threshold values for cotton, respectively (Maas and Grattan 1999). The amount of $\mathrm{N}$ was estimated with a

Table 1 Selected physical and chemical properties of the soil used

\begin{tabular}{lr}
\hline Characteristic & Value \\
\hline Clay (\%) & 18.4 \\
Silt (\%) & 40.5 \\
Sand (\%) & 41.1 \\
$\mathrm{EC}_{\mathrm{e}}\left(\mathrm{dS} \mathrm{m}{ }^{-1}\right)$ & 2.4 \\
$\mathrm{pH}\left(\mathrm{H}_{2} \mathrm{O}\right)$ & 7.5 \\
Organic matter $\left(\mathrm{OM}, \mathrm{g} \mathrm{kg}^{-1}\right)$ & 15.3 \\
Total nitrogen $\left(\mathrm{N}, \mathrm{g} \mathrm{kg}^{-1}\right)$ & 1.1 \\
Available phosphorus $\left(\mathrm{Olsen}-\mathrm{P}, \mathrm{mg} \mathrm{kg}^{-1}\right)$ & 19.0 \\
Available potassium $\left(\mathrm{K}, \mathrm{mg} \mathrm{kg}^{-1}\right)$ & 194 \\
\hline
\end{tabular}


population density of 221,000 plants ha ${ }^{-1}$ according to common field practices used by local farmers. The $\mathrm{N}$ application rates were $0,135,270$, and $405 \mathrm{~kg} \mathrm{ha}^{-1}$, which correspond to $0,2.65,5.30$, and $7.95 \mathrm{~g} \mathrm{~N}$ per pot in terms of plant population density, referred to as no (N0), low (NL), medium (NM), and high (NH) fertilization. The medium fertilization level was set based on the common field practices used by local farmers. The experiments followed a completely randomized block design with four replications for each treatment. Each block included 16 treatments.

Water was applied through drip irrigation units with a discharge rate of $1.1 \mathrm{~L} \mathrm{~h}^{-1}$. Drip laterals were installed on the top of the pots, and the emitter was fixed in the centre. Each pot was irrigated by one emitter. Cotton seeds were planted at $5 \mathrm{~cm}$ distance from the emitter in each pot on 28 May, and then the top of the pot was covered with a polyethylene film to reduce evaporation. Each pot received $9 \mathrm{~L}$ of water to help germination and seedling establishment. At the three-true-leaves stage (32-35 days after planting, DAP), the crop was thinned to four plants per pot, yielding a population of 221,000 plants $\mathrm{ha}^{-1}$. Drip irrigation were implemented from the squaring stage (50 DAP) to the boll opening stage (150 DAP). Fresh water (EC of $0.33 \mathrm{dS} \mathrm{m}^{-1}$ ) was used for all treatments. Two pots for each treatment were weighed every 2 days to keep the soil water content between $50 \%$ and $80 \%$ of the field capacity during the growing season. For each pot, the amount of water to be applied was determined by gathering water discharged from the emitter close to the pot. There was no drainage or leaching through the pots.

Triple superphosphate and potassium sulfate were applied as base fertilizers when filling the pots, while nitrogen fertilizer was applied through the drip irrigation system during the cotton growth period. Urea was used as the $\mathrm{N}$ source and applied in five equal splits at 50,65, 78, 90 and 108 DAP, according to common field practices used by local farmers. The fertilizer solution was stored in a plastic container of $100 \mathrm{~L}$ volume and pumped into the irrigation system. The experiment was terminated at the boll-opening stage (160 DAP).

\section{Sampling and measurement methods}

Plant height was measured weekly during the growth season. The shed (leaf, bud, flower, and boll) were collected daily for each pot. At the end of the experiment, plants were cut at the soil surface and separated into leaf, stem, bur, and seed. Roots were collected after the soil was passed through a $0.5-\mathrm{mm}$ sieve with the aid of a water jet. Debris, weeds and dead roots were sorted by hand from the 'live' roots during washing, based on visual observation that the 'live' roots appeared light in colors (Oikeh et al. 1999; Qu et al. 2003; Ruiz et al. 2005). Each plant component was washed with distilled water, dried in an oven at $70^{\circ} \mathrm{C}$ for $72 \mathrm{~h}$, and weighed. Dry masses of each component were measured and samples were grounded to pass through a 1-mm sieve. Soil samples were taken with a $0.03 \mathrm{~m}$ diameter tube sampler from three randomly chosen replicates of each treatment, at distances of $0-0.05,0.05-0.1,0.1-0.15$ and more than $0.15 \mathrm{~m}$ from the emitter. The soil cores were divided into $0.1 \mathrm{~m}$ increments to a depth of $0.5 \mathrm{~m}$, soil cores from the same treatment and depth were pooled, air dried, and a sub-sample was fine-ground with a mortar and pestle.

The gravimetric water content of the soil was measured via drying in an oven at $105^{\circ} \mathrm{C}$ for $48 \mathrm{~h}$. The EC of soil saturated-paste extract solution was determined with a DDS-308A conductivity meter (Shanghai Precision \& Scientific Instrument Inc., Shanghai, China). The plant samples were extracted with concentrated $\mathrm{H}_{2} \mathrm{SO}_{4}+\mathrm{H}_{2} \mathrm{O}_{2}$ before element analysis. Potassium and $\mathrm{Na}$ were determined by flame emission method (FP640, Shanghai Precision \& Scientific Instrument Inc., Shanghai, China), and Ca by atomic absorption spectrophotometry (AA6200, Shimadzu Corp., Kyoto, Japan). Chloride was extracted with boiling water and determined with an Orion ion specific electrode. Nitrogen content was analyzed using an Auto-Kjeldahl Unit (B-339, Buchi Labortechnik AG, Switzerland).

Plant water use was determined by summing water loss from the pots (Martin and Thorsteson 1988). Water use efficiency (WUE) was calculated as total dry mass (aboveground and root) divided by water use. Nitrogen uptake was calculated as the product of $\mathrm{N}$ content of each plant component (leaf, stem, bur, seed, shed, and root) and corresponding dry mass. Total $\mathrm{N}$ uptake was the sum of all plant parts. The apparent $\mathrm{N}$ recovery (ANR, \%) of different $\mathrm{N}$ application rates under the same salinity treatments was calculated as follows (Zemenchik and Albrecht 2002; Li et al. 2007):

$\operatorname{ANR}(\%)=100(a-b) / R$ 
where a is total $\mathrm{N}$ uptake in cotton $\left(\mathrm{g} \mathrm{pot}^{-1}\right)$ receiving $\mathrm{N}$ fertilizer; $\mathrm{b}$ is total $\mathrm{N}$ uptake in non-fertilized cotton $\left(\mathrm{g} \mathrm{pot}{ }^{-1}\right)$; $\mathrm{R}$ is the total amount of $\mathrm{N}$ applied $\left(\mathrm{g} \mathrm{pot}^{-1}\right)$.

Data analysis

The data were analyzed using the SPSS statistical program (version 11.5, SPSS Inc, 2003) with a twoway ANOVA at a significance level of 0.05 , with salinity and nitrogen as the independent variables. A Duncan multiple range test was carried out to determine if significant $(p<0.05)$ differences occurred between individual treatments.

\section{Results}

Plant height

During the early growth stage (planting to emergence, and to squaring), growth was significantly affected by the soil salinity level. The measured plant heights at 46 DAP decreased in proportion to the soil salinity level (Fig. 1). There was no significant difference $(P<$ $0.05)$ between different $\mathrm{N}$ treatments. The average plant height decreased from $30.3 \mathrm{~cm}$, to $19.7 \mathrm{~cm}$, $13.8 \mathrm{~cm}$ and to $6.0 \mathrm{~cm}$ as the soil salinity level increased from $2.4 \mathrm{dS} \mathrm{m}^{-1}$ to $7.7 \mathrm{dS} \mathrm{m}^{-1}, 12.5 \mathrm{dS} \mathrm{m}^{-1}$ and to $17.1 \mathrm{dS} \mathrm{m} \mathrm{m}^{-1}$, respectively. After the first fertigation (50 DAP), the plants went into a rapid growth period. The differences between treatment of S0, SL and SM were gradually reduced during this growth stage (squaring to full bloom). The full bloom appeared about 81 DAP under these three treatments. After that, the cotton height approached a plateau (Fig. 1). Under the $\mathrm{SH}$ treatment, the vegetative growth of cotton was significantly inhibited in the earlier growth stage in comparision with other salinity treatment. The inhibition was released by the irrigation and $\mathrm{N}$ application. After the first fertigation, the plant height rapidly increased from below $6 \mathrm{~cm}$ to above $60 \mathrm{~cm}$ at 88 DAP and then slowly reached a higher plateau than the other three treatments (on average of four $\mathrm{N}$ application rates).

The two-way ANOVA results showed that cotton height was significantly affected by salinity and $\mathrm{N}$ interaction, but not by $\mathrm{N}$ alone (Table 2). The influences of soil salinity and $\mathrm{N}$ application rate on cotton height at harvest are illustrated in Fig. 2. Under the treatments of S0, height increased with $\mathrm{N}$ application rates: under the $\mathrm{NH}$ treatment, the height was $17.5 \%$ and $14.1 \%$ higher than those under the N0 treatment and the NL treatment, respectively. Under
Fig. 1 Changes of cotton height with time under different soil salinity (ECe) levels: $2.4 \mathrm{dS} \mathrm{m}^{-1}$ (S0), $7.7 \mathrm{dS} \mathrm{m}^{-1}(\mathrm{SL})$,

$12.5 \mathrm{dS} \mathrm{m}^{-1}(\mathrm{SM})$, and $17.1 \mathrm{dS} \mathrm{m}^{-1}(\mathrm{SH})$ and $\mathrm{N}$ application rates: $0 \mathrm{~kg} \mathrm{ha}^{-1}$ (a), $135 \mathrm{~kg} \mathrm{ha}^{-1}$ (b), $270 \mathrm{~kg} \mathrm{ha}^{-1}$ (c), and $405 \mathrm{~kg} \mathrm{ha}^{-1}$ (d). The error bars refer to one standard deviation

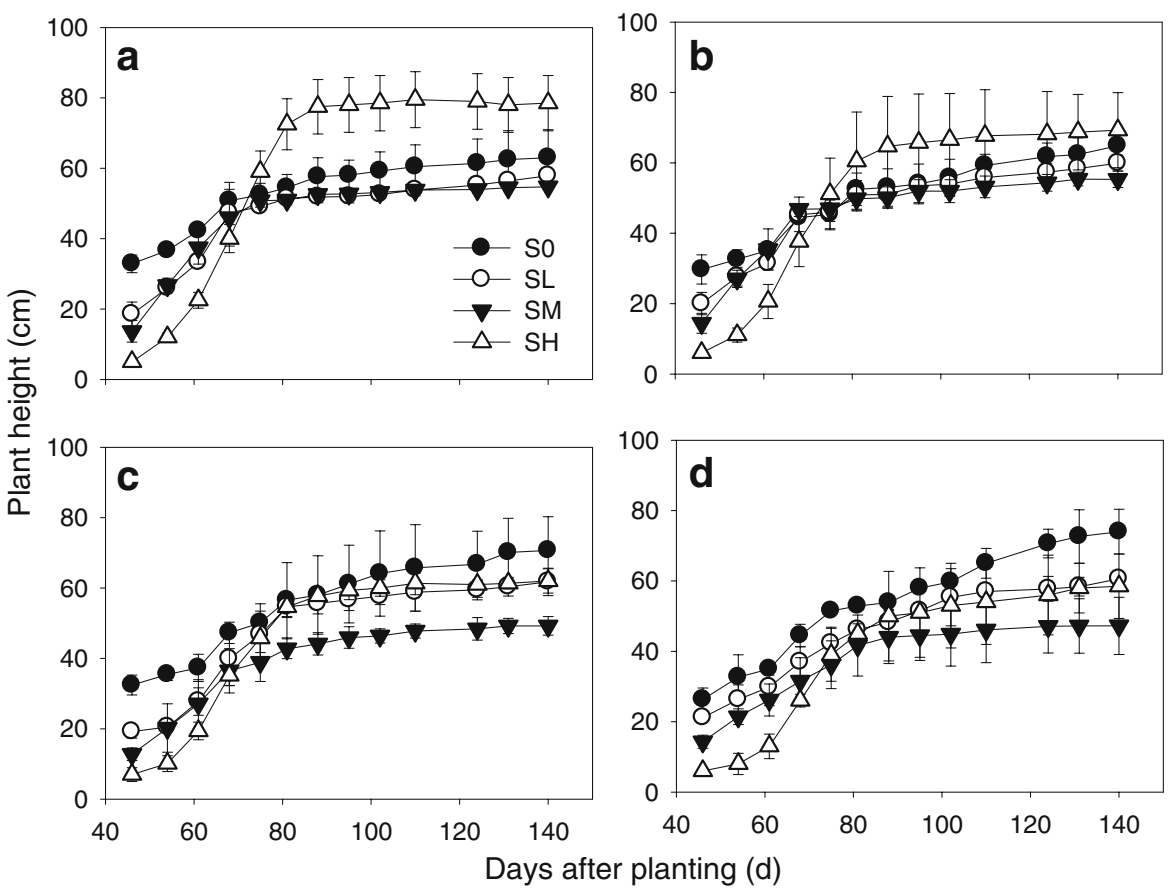


Table 2 Results of a two-way ANOVA of plant characteristics by salinity (S) and $\mathrm{N}$ treatments and their interactions
Numbers represent

F-values. ${ }^{*} P<0.05$;

${ }^{* *} P<0.01 ;{ }^{* * *} P<0.001$;

n.s., non-significant

\begin{tabular}{|c|c|c|c|}
\hline Dependent variable & $\mathrm{S}$ & $\mathrm{N}$ & $\mathrm{S} \times \mathrm{N}$ \\
\hline Plant height $(\mathrm{cm})$ & $33.4^{* * *}$ & 1.4 n.s. & $5.6^{* * *}$ \\
\hline Leaf dry weight $\left(\mathrm{g} \mathrm{pot}^{-1}\right)$ & $4.8^{* *}$ & 2.2 n.s. & $2.6^{*}$ \\
\hline Stem dry weight $\left(\mathrm{g} \mathrm{pot}^{-1}\right)$ & $32.3^{* * *}$ & 1.3 n.s. & $6.7^{* * *}$ \\
\hline Bur dry weight ( $\left.\mathrm{g} \mathrm{pot}^{-1}\right)$ & $54.3^{* * *}$ & $13.4^{* * *}$ & $5.7^{* * *}$ \\
\hline Seed dry weight $\left(\mathrm{g} \mathrm{pot}^{-1}\right)$ & $150.4^{* * *}$ & $13.9^{* * *}$ & $2.5^{*}$ \\
\hline Shed dry weight $\left(\mathrm{g}_{\text {pot }}{ }^{-1}\right)$ & $9.1^{* * *}$ & 0.6 n.s. & 0.7 n.s. \\
\hline Aboveground dry weight $\left(\mathrm{g} \operatorname{pot}^{-1}\right)$ & $312.8^{* * *}$ & $15.6^{* * *}$ & $9.2^{* * *}$ \\
\hline Root dry weight $\left(\mathrm{g} \mathrm{pot}^{-1}\right)$ & $50.1^{* * *}$ & 0.4 n.s. & 0.6 n.s. \\
\hline Water use efficiency (WUE, $\mathrm{g}^{-1}$ ) & $92.4^{* * *}$ & $14.9^{* * *}$ & $6.9^{* * *}$ \\
\hline $\mathrm{N}$ content in leaf $\left(\mathrm{g} \mathrm{pot}^{-1}\right)$ & $17.9^{* * *}$ & $12.4^{* * *}$ & $4.3^{* *}$ \\
\hline $\mathrm{N}$ content in stem $\left(\mathrm{g} \mathrm{pot}^{-1}\right)$ & $16.5^{* * *}$ & 1.5 n.s. & $5.0^{* * *}$ \\
\hline $\mathrm{N}$ content in bur $\left(\mathrm{g} \mathrm{pot}^{-1}\right)$ & $34.4^{* * *}$ & $21.8^{* * *}$ & $6.5^{* * *}$ \\
\hline $\mathrm{N}$ content in seed $\left(\mathrm{g} \mathrm{pot}^{-1}\right)$ & $273.8^{* * *}$ & $34.1^{* * *}$ & $4.2^{* *}$ \\
\hline $\mathrm{N}$ content in shed $\left(\mathrm{g} \mathrm{pot}^{-1}\right)$ & $8.4^{* * *}$ & 0.8 n.s. & 1.4 n.s. \\
\hline $\mathrm{N}$ content in root $\left(\mathrm{g} \mathrm{pot}^{-1}\right)$ & $57.1^{* * *}$ & 2.4 n.s. & 1.7 n.s. \\
\hline Total $\mathrm{N}$ uptake $\left(\mathrm{g} \mathrm{pot}^{-1}\right)$ & $152.5^{* * *}$ & $25.7^{* * *}$ & $3.6^{* *}$ \\
\hline Apparent $\mathrm{N}$ recovery (ANR, \%) & $44.7^{* * *}$ & $121.0^{* * *}$ & $3.3^{*}$ \\
\hline $\mathrm{K}$ concentration in leaf $\left(\mathrm{g} \mathrm{kg}^{-1}\right)$ & $36.6^{* * *}$ & 0.9 n.s. & $1.0 \mathrm{n} . \mathrm{s}$. \\
\hline $\mathrm{K}$ concentration in stem $\left(\mathrm{g} \mathrm{kg}^{-1}\right)$ & $15.0^{* * *}$ & 2.7 n.s. & 1.9 n.s. \\
\hline $\mathrm{K}$ concentration in bur $\left(\mathrm{g} \mathrm{kg}^{-1}\right)$ & $10.7^{* * *}$ & 0.9 n.s. & 2.3 n.s. \\
\hline $\mathrm{K}$ concentration in seed $\left(\mathrm{g} \mathrm{kg}^{-1}\right)$ & 1.6 n.s. & 0.3 n.s. & 1.0 n.s. \\
\hline $\mathrm{Na}$ concentration in leaf $\left(\mathrm{g} \mathrm{kg}^{-1}\right)$ & $472.6^{* * *}$ & 1.0 n.s. & 0.5 n.s. \\
\hline $\mathrm{Na}$ concentration in stem $\left(\mathrm{g} \mathrm{kg}^{-1}\right)$ & $421.2^{* * *}$ & 2.4 n.s. & 1.5 n.s. \\
\hline $\mathrm{Na}$ concentration in bur $\left(\mathrm{g} \mathrm{kg}^{-1}\right)$ & $255.1^{* * *}$ & 0.7 n.s. & 2.1 n.s. \\
\hline $\mathrm{Na}$ concentration in seed $\left(\mathrm{g} \mathrm{kg}^{-1}\right)$ & 2.4 n.s. & 2.3 n.s. & 2.1 n.s. \\
\hline Ca concentration in leaf $\left(\mathrm{g} \mathrm{kg}^{-1}\right)$ & $171.8^{* * *}$ & $10.7^{* * *}$ & 1.6 n.s. \\
\hline Ca concentration in stem $\left(\mathrm{g} \mathrm{kg}^{-1}\right)$ & $25.2^{* * *}$ & $11.8^{* * *}$ & 1.2 n.s. \\
\hline Ca concentration in bur $\left(\mathrm{g} \mathrm{kg}^{-1}\right)$ & $24.9^{* * *}$ & $14.0 * *$ & 1.3 n.s. \\
\hline Ca concentration in seed $\left(\mathrm{g} \mathrm{kg}^{-1}\right)$ & 2.1 n.s. & 1.3 n.s. & 1.8 n.s. \\
\hline $\mathrm{Cl}$ concentration in leaf $\left(\mathrm{g} \mathrm{kg}^{-1}\right)$ & $211.9^{* * *}$ & 2.8 n.s. & 0.8 n.s. \\
\hline $\mathrm{Cl}$ concentration in stem $\left(\mathrm{g} \mathrm{kg}^{-1}\right)$ & $99.8^{* * *}$ & 2.1 n.s. & 0.4 n.s. \\
\hline $\mathrm{Cl}$ concentration in bur $\left(\mathrm{g} \mathrm{kg}^{-1}\right)$ & $76.5^{* * *}$ & 1.6 n.s. & 0.7 n.s. \\
\hline $\mathrm{Cl}$ concentration in seed $\left(\mathrm{g} \mathrm{kg}^{-1}\right)$ & 0.6 n.s. & 1.7 n.s. & 0.5 n.s. \\
\hline
\end{tabular}

the treatments of SL, $\mathrm{N}$ application rates had no significant effects on the cotton growth, while with the treatments of SM and SH, plant height decreased with $\mathrm{N}$ application rate. The height under the treatment of N0 was about $20 \%$ higher than that under the treatment of $\mathrm{NH}$. With treatments of $\mathrm{N} 0$ and NL, height under the high soil salinity treatment ( $\mathrm{SH}$ treatment) was significantly higher than under the other three treatments. With treatments of NM and $\mathrm{NL}$, height under different salinity treatment followed a decreasing of $\mathrm{S} 0>\mathrm{SL}$ and $\mathrm{SH}>\mathrm{SM}$.

\section{Above-ground biomass}

The effects of salt and $\mathrm{N}$ treatments on dry mass of cotton plant parts (leaf, stem, bur, seed and shed) are summarized in Table 3. The dry mass of different cotton plant parts were all significantly affected by the soil salinity levels (Table 2). The dry mass of cotton leaf and stem in the $2.4 \mathrm{dS} \mathrm{m}^{-1}$ (S0) treatment was significantly greater by about $12 \%$ and $30 \%$ than under the other three treatments, respectively. The dry mass of cotton bur decreased linearly from $51.5 \mathrm{~g} \mathrm{pot}^{-1}$, to $43.7 \mathrm{~g} \mathrm{pot}^{-1}$, to $34.0 \mathrm{~g} \mathrm{pot}^{-1}$, and to $28.3 \mathrm{~g} \mathrm{pot}^{-1}$ as the soil salinity level increased from $2.4 \mathrm{dS} \mathrm{m}^{-1}$, to $7.7 \mathrm{dS} \mathrm{m}^{-1}$, to $12.5 \mathrm{dS} \mathrm{m}^{-1}$, and to $17.1 \mathrm{dS} \mathrm{m}^{-1}$, respectively. For the seed, the effect of soil salinity was even more pronounced, especially under the high soil salinity treatment. The dry mass of seed was reduced by $22 \%, 108 \%$, and $514 \%$ respectively, when the soil salinity level increased from the control level of $2.4 \mathrm{dS} \mathrm{m}^{-1}$ to $7.7 \mathrm{dS} \mathrm{m}^{-1}, 12.5 \mathrm{dS} \mathrm{m}^{-1}$ 


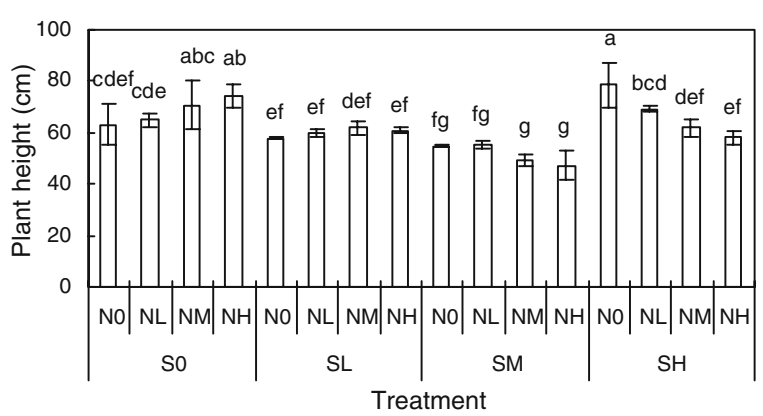

Fig. 2 Effect of soil salinity and $\mathrm{N}$ levels on plant height of cotton in full development stage. Bars represent mean \pm SD. Different letters indicate significant difference $(P<0.05)$. The symbols, S0, SL, SM, and SH, are corresponding to the soil salinity (ECe) of $2.4,7.7,12.5$ and $17.1 \mathrm{dS} \mathrm{m}^{-1}$, respectively. The symbols, N0, NL, NM, and NH are corresponding to the N application of $0,135,270$, and $405 \mathrm{~kg} \mathrm{ha}^{-1}$, respectively. The symbols (S0, SL, SM, and SH; NO, NL, NM, and NH) in the following tables and figures are the same as those in this figure

and to $17.1 \mathrm{dS} \mathrm{m} \mathrm{m}^{-1}$, respectively. The dry mass of shed under soil salinity treatments of SM and $\mathrm{SH}$ were significantly lower than those under lower soil salinity treatments. But, the average ratio of shed to total biomass under the high soil salinity treatment (0.16) was much higher than the other treatments (0.09-0.12).

The effects of $\mathrm{N}$ application rates on dry mass of different cotton plant tissues were insignificant except for cotton bur and seed (Table 2). The average dry mass of cotton bur under different $\mathrm{N}$ treatments followed a decreasing order of NM (45.0 $\left.\mathrm{g} \mathrm{pot}^{-1}\right)>$ $\mathrm{NH}\left(41.6 \mathrm{~g} \mathrm{pot}^{-1}\right)>\mathrm{NL}\left(37.4 \mathrm{~g} \mathrm{pot}^{-1}\right)>\mathrm{N} 0(33.3 \mathrm{~g}$ $\left.\operatorname{pot}^{-1}\right)$. The average dry mass of seed followed in decreasing order of NL $\left(50.2 \mathrm{~g} \mathrm{pot}^{-1}\right)>\mathrm{NM}(48.5 \mathrm{~g}$ $\left.\operatorname{pot}^{-1}\right)>\mathrm{NH}\left(38.9 \mathrm{~g} \mathrm{pot}^{-1}\right)>\mathrm{N} 0\left(33.8 \mathrm{~g} \mathrm{pot}^{-1}\right)$. The average dry mass of seed under the $\mathrm{N}$ application rate of 135 and $270 \mathrm{~kg} \mathrm{~N}$ ha ${ }^{-1}$ was significantly higher than those under the $\mathrm{N}$ application rates of 0 and $405 \mathrm{~kg} \mathrm{~N} \mathrm{ha}^{-1}$.

The total aboveground dry mass of cotton was significantly affected by salinity, $\mathrm{N}$, and $\mathrm{N} \times$ salinity interaction (Table 2). The total dry mass under the $\mathrm{N}$ application rate of $135 \mathrm{~kg} \mathrm{~N}^{-1}$ was the highest, which was about $14 \%$ greater the treatment without $\mathrm{N}$ application (Table 3). There was no significant difference of the total dry mass under the $\mathrm{N}$ application rate of 135, 270 and $405 \mathrm{~kg} \mathrm{~N} \mathrm{ha}^{-1}$. The total dry mass decreased linearly as the soil salinity increased. On average, the total dry mass under the treatment of S0 was 23, 60, and $84 \%$ higher than those under the soil salinity treatments of SL, SM and $\mathrm{SH}$, respectively.

Root biomass and distribution

Statistical analysis showed that the cotton root mass was significantly affected by the soil salinity

Table 3 Aboveground dry mass $\left(\mathrm{g}\right.$ pot $\left.{ }^{-1}\right)$ under different soil salinity and $\mathrm{N}$ treatments

\begin{tabular}{llllllll}
\hline Salinity level & N level & Leaf & Stem & Bur & Seed & Shed & Total \\
\hline S0 & N0 & $52.9 \pm 0.9 \mathrm{bc}$ & $38.9 \pm 0.1 \mathrm{~cd}$ & $46.9 \pm 1.1 \mathrm{~b}$ & $51.4 \pm 2.6 \mathrm{~cd}$ & $29.8 \pm 3.5 \mathrm{abc}$ & $219.9 \pm 1.0 \mathrm{~cd}$ \\
& NL & $48.8 \pm 0.4 \mathrm{bc}$ & $41.1 \pm 1.8 \mathrm{c}$ & $40.5 \pm 2.6 \mathrm{bcd}$ & $81.0 \pm 3.2 \mathrm{a}$ & $35.5 \pm 4.2 \mathrm{a}$ & $246.9 \pm 0.6 \mathrm{~b}$ \\
& NM & $58.0 \pm 0.7 \mathrm{~b}$ & $51.1 \pm 9.1 \mathrm{~b}$ & $59.9 \pm 1.2 \mathrm{a}$ & $78.3 \pm 4.9 \mathrm{a}$ & $33.7 \pm 9.5 \mathrm{ab}$ & $281.0 \pm 3.7 \mathrm{a}$ \\
& NH & $68.2 \pm 14.0 \mathrm{a}$ & $62.4 \pm 6.7 \mathrm{a}$ & $58.5 \pm 11.0 \mathrm{a}$ & $72.5 \pm 2.7 \mathrm{ab}$ & $33.0 \pm 7.8 \mathrm{ab}$ & $294.6 \pm 26.6 \mathrm{a}$ \\
SL & N0 & $51.8 \pm 1.4 \mathrm{bc}$ & $37.6 \pm 2.5 \mathrm{cde}$ & $41.5 \pm 3.8 \mathrm{bc}$ & $42.6 \pm 3.2 \mathrm{~d}$ & $20.5 \pm 0.9 \mathrm{abcd}$ & $194.0 \pm 3.8 \mathrm{ef}$ \\
& NL & $55.2 \pm 5.5 \mathrm{~b}$ & $36.0 \pm 5.0 \mathrm{cdef}$ & $42.7 \pm 0.3 \mathrm{bc}$ & $68.5 \pm 14.2 \mathrm{ab}$ & $28.2 \pm 10.1 \mathrm{abc}$ & $230.5 \pm 6.8 \mathrm{bc}$ \\
& NM & $47.6 \pm 4.8 \mathrm{bc}$ & $36.3 \pm 3.6 \mathrm{cdef}$ & $43.2 \pm 5.3 \mathrm{bc}$ & $61.4 \pm 4.0 \mathrm{bc}$ & $24.1 \pm 6.3 \mathrm{abcd}$ & $212.7 \pm 11.3 \mathrm{~cd}$ \\
& NH & $49.1 \pm 2.0 \mathrm{bc}$ & $38.9 \pm 4.5 \mathrm{~cd}$ & $47.3 \pm 1.8 \mathrm{~b}$ & $47.6 \pm 2.4 \mathrm{~d}$ & $23.9 \pm 4.5 \mathrm{abcd}$ & $206.9 \pm 5.2 \mathrm{de}$ \\
SM & N0 & $44.0 \pm 0.6 \mathrm{a}$ & $33.7 \pm 1.9 \mathrm{cdefg}$ & $32.3 \pm 0.3 \mathrm{de}$ & $29.1 \pm 6.7 \mathrm{e}$ & $16.1 \pm 0.6 \mathrm{bcd}$ & $155.3 \pm 6.4 \mathrm{hi}$ \\
& NL & $52.1 \pm 7.7 \mathrm{bc}$ & $37.6 \pm 2.9 \mathrm{cde}$ & $36.4 \pm 5.7 \mathrm{cde}$ & $40.0 \pm 1.4 \mathrm{de}$ & $13.8 \pm 2.4 \mathrm{~cd}$ & $179.8 \pm 15.3 \mathrm{fg}$ \\
& NM & $47.8 \pm 0.6 \mathrm{bc}$ & $29.0 \pm 2.3 \mathrm{efg}$ & $36.8 \pm 1.2 \mathrm{cde}$ & $39.1 \pm 0.5 \mathrm{de}$ & $10.3 \pm 8.3 \mathrm{~d}$ & $162.9 \pm 14.9 \mathrm{gh}$ \\
& NH & $51.5 \pm 7.0 \mathrm{bc}$ & $28.4 \pm 6.9 \mathrm{fg}$ & $30.3 \pm 0.2 \mathrm{e}$ & $28.0 \pm 6.1 \mathrm{e}$ & $14.8 \pm 1.9 \mathrm{~cd}$ & $153.0 \pm 9.8 \mathrm{hi}$ \\
SH & N0 & $52.8 \pm 1.1 \mathrm{bc}$ & $33.0 \pm 1.0 \mathrm{cdefg}$ & $12.4 \pm 2.1 \mathrm{f}$ & $12.1 \pm 0.3 \mathrm{f}$ & $26.3 \pm 6.3 \mathrm{abcd}$ & $136.6 \pm 6.6 \mathrm{i}$ \\
& NL & $50.7 \pm 0.4 \mathrm{bc}$ & $30.5 \pm 0.5 \mathrm{defg}$ & $30.1 \pm 3.5 \mathrm{e}$ & $11.4 \pm 0.1 \mathrm{f}$ & $18.0 \pm 1.7 \mathrm{abcd}$ & $140.8 \pm 0.8 \mathrm{i}$ \\
& NM & $48.0 \pm 9.0 \mathrm{bc}$ & $37.3 \pm 7.8 \mathrm{cdef}$ & $40.2 \pm 8.0 \mathrm{cde}$ & $15.1 \pm 11.8 \mathrm{f}$ & $10.0 \pm 7.2 \mathrm{~d}$ & $150.6 \pm 12.3 \mathrm{hi}$ \\
& NH & $52.6 \pm 6.1 \mathrm{bc}$ & $26.1 \pm 5.7 \mathrm{~g}$ & $30.4 \pm 9.1 \mathrm{e}$ & $7.5 \pm 1.9 \mathrm{f}$ & $22.7 \pm 12.7 \mathrm{abcd}$ & $139.3 \pm 0.2 \mathrm{i}$ \\
\hline
\end{tabular}

Mean values \pm SD are shown. Different letters in the same column indicate significant difference $(P<0.05)$. The symbols represent as in Fig. 2 
$(p<0.001)$, while the effects of the $\mathrm{N}$ application $(p>$ $0.05)$ and $\mathrm{N} \times$ salinity interaction $(p>0.05)$ on root mass were quite limited (Table 2). In general, the root mass decreased with soil salinity level under the same $\mathrm{N}$ application rate (Table 4). The average root masses under the salinity level of S0, SL and SM were about 1.6, 1.4 and 1.2 times, respectively, higher than that under the salinity level of SH.

The root distribution followed a similar pattern under different soil salinity levels, namely, the amounts of root decreased with soil depth and the majority of the roots (80-90\%) were distributed in the top $20 \mathrm{~cm}$ (Table 4). Under the high soil salinity treatment $(\mathrm{SH})$, the root distribution ratio in the top $10 \mathrm{~cm}$ layer was significantly lower than those under low soil salinity treatment ( $\mathrm{S} 0$ and SL). Compared to the treatment of $\mathrm{S} 0$, the root distribution ratio in the top $10 \mathrm{~cm}$ layer under treatment of $\mathrm{SH}$ was reduced by about $4 \%$. There was no significant difference of the root distribution ratio in the $10-30 \mathrm{~cm}$ layer under different salinity treatments. As the soil salinity increased, more roots were distributed in $30-50 \mathrm{~cm}$ soil layers. Compared to the treatment of $\mathrm{S} 0$, the root distribution ratio in the bottom $30-50 \mathrm{~cm}$ layer under treatment of SH increased by about $4 \%$.
Water use efficiency

Water use efficiency (WUE) of cotton was significantly affected by salinity, $\mathrm{N}$, and $\mathrm{N} \times$ salinity interaction (Table 2, Fig. 3). Generally, WUE of cotton decreased as the soil salinity level increased. Under treatment of S0, WUE of cotton significantly increased with $\mathrm{N}$ application rate. WUE under $\mathrm{N}$ application rate of $405 \mathrm{~kg} \mathrm{~N} \mathrm{ha}^{-1}$ (NH treatment) was $37 \%$ and $20 \%$ greater than that under $\mathrm{N}$ application rate of 0 and $135 \mathrm{~kg} \mathrm{~N} \mathrm{ha}^{-1}$ (N0 and NL treatment), respectively, but was not significantly different from that under the NM treatment. Under the low and medium salinity conditions (SL and SM treatments), the highest WUE was found under the treatment of NL. Under the high salinity condition (SH treatment), there was no significant difference of WUE between different $\mathrm{N}$ application rates.

\section{Nitrogen uptake and apparent $\mathrm{N}$ recovery}

The effects of salt and $\mathrm{N}$ treatments on uptake of $\mathrm{N}$ are summarized in Tables 2 and 5. Under the four different $\mathrm{N}$ application rates, $\mathrm{N}$ uptake of all decreased as soil salinity increased. On average, the

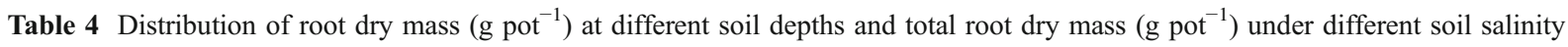
and $\mathrm{N}$ treatments

\begin{tabular}{|c|c|c|c|c|c|c|c|}
\hline \multirow[t]{2}{*}{ Salinity level } & \multirow[t]{2}{*}{$\mathrm{N}$ level } & \multicolumn{5}{|l|}{ Soil depth (m) } & \multirow[t]{2}{*}{ Total root mass } \\
\hline & & $0-0.1$ & $0.1-0.2$ & $0.2-0.3$ & $0.3-0.4$ & $0.4-0.5$ & \\
\hline \multirow[t]{4}{*}{ S0 } & No & $15.87 \pm 1.12 \mathrm{ab}$ & $3.99 \pm 0.28 \mathrm{a}$ & $1.30 \pm 0.09 \mathrm{ab}$ & $0.83 \pm 0.06 \mathrm{ab}$ & $0.43 \pm 0.03 \mathrm{~d}$ & $22.43 \pm 1.58 \mathrm{a}$ \\
\hline & NL & $17.03 \pm 1.54 \mathrm{a}$ & $3.70 \pm 0.33 \mathrm{a}$ & $1.29 \pm 0.12 \mathrm{abc}$ & $0.85 \pm 0.08 \mathrm{ab}$ & $0.53 \pm 0.05 \mathrm{bcd}$ & $23.39 \pm 2.11 \mathrm{a}$ \\
\hline & NM & $16.10 \pm 0.37 \mathrm{a}$ & $3.71 \pm 0.08 \mathrm{a}$ & $1.46 \pm 0.03 \mathrm{a}$ & $0.84 \pm 0.02 \mathrm{ab}$ & $0.49 \pm 0.01 \mathrm{~cd}$ & $22.61 \pm 0.52 \mathrm{a}$ \\
\hline & $\mathrm{NH}$ & $16.30 \pm 1.68 \mathrm{a}$ & $3.76 \pm 0.39 \mathrm{a}$ & $1.48 \pm 0.15 \mathrm{a}$ & $0.85 \pm 0.09 \mathrm{ab}$ & $0.50 \pm 0.05 \mathrm{bcd}$ & $22.89 \pm 2.36 \mathrm{a}$ \\
\hline \multirow[t]{4}{*}{ SL } & N0 & $15.38 \pm 0.77 \mathrm{ab}$ & $2.95 \pm 0.15 \mathrm{~b}$ & $1.23 \pm 0.06 \mathrm{bc}$ & $0.96 \pm 0.05 \mathrm{a}$ & $0.61 \pm 0.03 \mathrm{ab}$ & $21.13 \pm 1.06 \mathrm{ab}$ \\
\hline & NL & $13.73 \pm 1.04 \mathrm{bc}$ & $3.02 \pm 0.23 \mathrm{~b}$ & $1.16 \pm 0.09 \mathrm{bcd}$ & $0.81 \pm 0.06 \mathrm{bc}$ & $0.54 \pm 0.04 \mathrm{bc}$ & $19.26 \pm 1.46 \mathrm{bc}$ \\
\hline & NM & $13.69 \pm 0.61 \mathrm{bc}$ & $2.00 \pm 0.09 \mathrm{~d}$ & $1.33 \pm 0.06 \mathrm{ab}$ & $0.77 \pm 0.03 \mathrm{bcd}$ & $0.53 \pm 0.02 \mathrm{bcd}$ & $18.31 \pm 0.82 \mathrm{bc}$ \\
\hline & $\mathrm{NH}$ & $13.66 \pm 0.69 \mathrm{bc}$ & $1.99 \pm 0.10 \mathrm{~d}$ & $1.33 \pm 0.07 \mathrm{ab}$ & $0.77 \pm 0.04 \mathrm{bcd}$ & $0.53 \pm 0.03 \mathrm{bcd}$ & $18.28 \pm 0.92 \mathrm{bc}$ \\
\hline \multirow[t]{4}{*}{ SM } & No & $10.68 \pm 0.58 \mathrm{de}$ & $2.93 \pm 0.16 \mathrm{~b}$ & $0.85 \pm 0.05 \mathrm{f}$ & $0.85 \pm 0.05 \mathrm{ab}$ & $0.67 \pm 0.04 \mathrm{a}$ & $15.98 \pm 0.87 \mathrm{cde}$ \\
\hline & NL & $11.25 \pm 1.01 \mathrm{de}$ & $2.53 \pm 0.23 \mathrm{bcd}$ & $0.94 \pm 0.08$ ef & $0.75 \pm 0.07 \mathrm{bcd}$ & $0.60 \pm 0.05 \mathrm{abc}$ & $16.07 \pm 1.44 \mathrm{cde}$ \\
\hline & NM & $12.10 \pm 0.14 \mathrm{~cd}$ & $2.68 \pm 0.03 \mathrm{bc}$ & $1.01 \pm 0.01 \mathrm{def}$ & $0.68 \pm 0.01 \mathrm{~cd}$ & $0.60 \pm 0.01 \mathrm{abc}$ & $17.06 \pm 0.20 \mathrm{~cd}$ \\
\hline & $\mathrm{NH}$ & $11.64 \pm 0.46 \mathrm{cde}$ & $2.58 \pm 0.10 \mathrm{bcd}$ & $0.97 \pm 0.04$ def & $0.65 \pm 0.03 \mathrm{~d}$ & $0.57 \pm 0.02 \mathrm{abc}$ & $16.41 \pm 0.64 \mathrm{cde}$ \\
\hline \multirow[t]{4}{*}{$\mathrm{SH}$} & No & $9.85 \pm 0.92 \mathrm{de}$ & $2.13 \pm 0.20 \mathrm{de}$ & $1.09 \pm 0.10 \mathrm{cde}$ & $0.83 \pm 0.08 \mathrm{ab}$ & $0.65 \pm 0.06 \mathrm{a}$ & $14.55 \pm 1.36 \mathrm{de}$ \\
\hline & NL & $9.35 \pm 0.49 \mathrm{e}$ & $2.02 \pm 0.11 \mathrm{~d}$ & $0.86 \pm 0.04 \mathrm{f}$ & $0.71 \pm 0.04 \mathrm{bcd}$ & $0.59 \pm 0.03 \mathrm{abc}$ & $13.53 \pm 0.70 \mathrm{e}$ \\
\hline & NM & $9.28 \pm 0.60 \mathrm{cde}$ & $2.29 \pm 0.15 \mathrm{~cd}$ & $0.90 \pm 0.06$ ef & $0.70 \pm 0.05 \mathrm{bcd}$ & $0.65 \pm 0.04 \mathrm{a}$ & $13.82 \pm 0.89 \mathrm{de}$ \\
\hline & $\mathrm{NH}$ & $9.55 \pm 0.91 \mathrm{cde}$ & $2.36 \pm 0.22 \mathrm{~cd}$ & $0.93 \pm 0.09$ ef & $0.72 \pm 0.07 \mathrm{bcd}$ & $0.67 \pm 0.06 \mathrm{a}$ & $14.22 \pm 1.35 \mathrm{de}$ \\
\hline
\end{tabular}

Mean values \pm SD are shown. Different letters in the same column indicate significant difference $(P<0.05)$. The symbols represent as in Fig. 2 


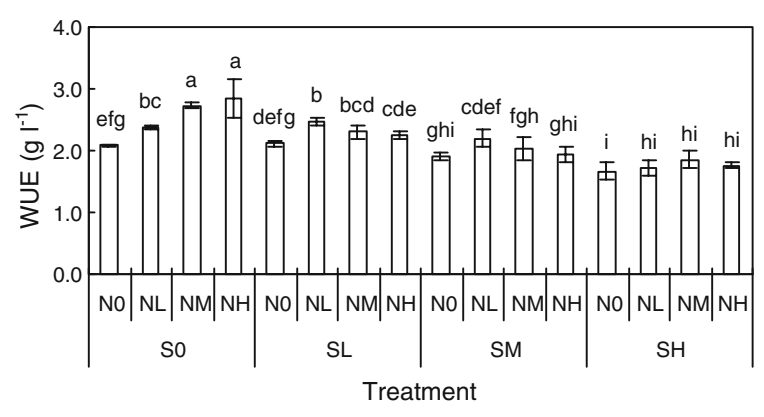

Fig. 3 Effect of soil salinity and $\mathrm{N}$ levels on water use efficiency (WUE, $\mathrm{g}^{-1}$ ) of cotton. Bars represent mean \pm SD. Different letters indicate significant difference $(P<0.05)$. The symbols are the same as in Fig. 2

total $\mathrm{N}$ uptake decreased from $6.39 \mathrm{~g} \mathrm{pot}^{-1}$, to $4.85 \mathrm{~g}$ $\operatorname{pot}^{-1}, 3.77 \mathrm{~g} \mathrm{pot}^{-1}$ and to $3.05 \mathrm{~g} \mathrm{pot}^{-1}$, respectively, as the soil salinity level progressively increased. Under the treatment of S0, the total $\mathrm{N}$ uptake increased with the $\mathrm{N}$ application rates. The total $\mathrm{N}$ uptake under $\mathrm{N}$ application rate of $405 \mathrm{~kg} \mathrm{~N}^{-1}$ was about $46 \%$ greater than that under the treatment without $\mathrm{N}$ application. Under the treatment of SL and $\mathrm{SM}$, the total $\mathrm{N}$ uptake under $\mathrm{N}$ application rates of $135 \mathrm{~kg} \mathrm{ha}^{-1}$ and $270 \mathrm{~kg} \mathrm{ha}^{-1}$ was significantly greater than that under the two higher $\mathrm{N}$ treatments.
Under the treatment of $\mathrm{SH}$, there was no significant difference of total $\mathrm{N}$ uptake between different $\mathrm{N}$ application rates. Overall, the total $\mathrm{N}$ uptake under the different $\mathrm{N}$ application rates followed in a decreasing order of NM $\left(5.04 \mathrm{~g} \mathrm{pot}^{-1}\right)>\mathrm{NL}\left(4.76 \mathrm{~g} \mathrm{pot}^{-1}\right)>\mathrm{NH}$ $\left(4.59 \mathrm{~g} \mathrm{pot}^{-1}\right)>\mathrm{N} 0\left(3.67 \mathrm{~g} \mathrm{pot}^{-1}\right)$.

Apparent $\mathrm{N}$ recovery (ANR) of cotton was significantly affected by salinity $(p<0.001), \mathrm{N}(p<0.001)$, and $\mathrm{N} \times$ salinity interaction $(p<0.05)$ (Table 2$)$. In general, ANR decreased with $\mathrm{N}$ application rate (Fig. 4). On average, ANR decreased from $41 \%$, to $26 \%$, and to $12 \%$, respectively, as the $\mathrm{N}$ application rate increased from 135 , to 270 , and to $405 \mathrm{~kg} \mathrm{ha}^{-1}$. The ANR also was significantly reduced by soil salinity. The highest ANR was found in S0 treatment and the lowest in SH treatment, but there was no significant difference between NL and NM treatments (Fig. 4).

Salt ion uptake

Effects of $\mathrm{N}$ application rate and salinity on concentrations of $\mathrm{K}, \mathrm{Na}, \mathrm{Ca}$ and $\mathrm{Cl}$ in different plant parts after harvest are presented in Table 2. Except for seed, the concentrations of these four ions in plant parts were significantly affected by the soil salinity. The

Table $5 \mathrm{~N}$ uptake $\left(\mathrm{g} \mathrm{pot}^{-1}\right)$ as influenced by soil salinity and $\mathrm{N}$ treatments

\begin{tabular}{llllllllll}
\hline $\begin{array}{l}\text { Salinity } \\
\text { level }\end{array}$ & N level Leaf & & Stem & Bur & Seed & Shed & Root & Total \\
\hline S0 & & & & & & & & \\
& & & & & & & \\
& NL & $1.23 \pm 0.12 \mathrm{~cd}$ & $0.58 \pm 0.14 \mathrm{cde}$ & $0.88 \pm 0.12 \mathrm{~cd}$ & $1.45 \pm 0.07 \mathrm{~d}$ & $0.42 \pm 0.05 \mathrm{abc}$ & $0.33 \pm 0.03 \mathrm{~b}$ & $4.90 \pm 0.57 \mathrm{~cd}$ \\
& $\mathrm{NM}$ & $1.48 \pm 0.11 \mathrm{bc}$ & $0.70 \pm 0.11 \mathrm{bc}$ & $0.77 \pm 0.05 \mathrm{cde}$ & $2.46 \pm 0.10 \mathrm{ab}$ & $0.46 \pm 0.05 \mathrm{ab}$ & $0.41 \pm 0.05 \mathrm{a}$ & $6.17 \pm 0.35 \mathrm{~b}$ \\
& $\mathrm{NH}$ & $1.64 \pm 0.34 \mathrm{a}$ & $1.03 \pm 0.21 \mathrm{a}$ & $1.13 \pm 0.21 \mathrm{~b}$ & $2.29 \pm 0.09 \mathrm{~b}$ & $0.59 \pm 0.14 \mathrm{a}$ & $0.48 \pm 0.07 \mathrm{a}$ & $7.16 \pm 0.76 \mathrm{a}$ \\
$\mathrm{SL}$ & $\mathrm{N} 0$ & $1.08 \pm 0.03 \mathrm{~d}$ & $0.62 \pm 0.08 \mathrm{bcd}$ & $0.77 \pm 0.07 \mathrm{cde}$ & $1.15 \pm 0.07 \mathrm{de}$ & $0.23 \pm 0.01 \mathrm{~cd}$ & $0.26 \pm 0.04 \mathrm{bcde}$ & $4.11 \pm 0.35 \mathrm{ef}$ \\
& $\mathrm{NL}$ & $1.25 \pm 0.12 \mathrm{~cd}$ & $0.65 \pm 0.09 \mathrm{bcd}$ & $0.86 \pm 0.11 \mathrm{~cd}$ & $1.80 \pm 0.37 \mathrm{c}$ & $0.37 \pm 0.13 \mathrm{abc}$ & $0.30 \pm 0.03 \mathrm{bcd}$ & $5.23 \pm 0.31 \mathrm{c}$ \\
& $\mathrm{NM}$ & $1.09 \pm 0.11 \mathrm{~d}$ & $0.62 \pm 0.06 \mathrm{bcd}$ & $0.84 \pm 0.10 \mathrm{~cd}$ & $1.97 \pm 0.13 \mathrm{c}$ & $0.50 \pm 0.13 \mathrm{ab}$ & $0.32 \pm 0.02 \mathrm{bc}$ & $5.34 \pm 0.27 \mathrm{c}$ \\
& $\mathrm{NH}$ & $1.05 \pm 0.04 \mathrm{~d}$ & $0.65 \pm 0.08 \mathrm{bcd}$ & $0.91 \pm 0.13 \mathrm{~cd}$ & $1.41 \pm 0.07 \mathrm{~d}$ & $0.42 \pm 0.08 \mathrm{abc}$ & $0.30 \pm 0.05 \mathrm{bcd}$ & $4.73 \pm 0.43 \mathrm{cde}$ \\
$\mathrm{SM}$ & $\mathrm{N} 0$ & $0.79 \pm 0.06 \mathrm{e}$ & $0.47 \pm 0.07 \mathrm{de}$ & $0.55 \pm 0.07 \mathrm{e}$ & $0.73 \pm 0.17 \mathrm{~g}$ & $0.27 \pm 0.01 \mathrm{bc}$ & $0.24 \pm 0.03 \mathrm{de}$ & $3.05 \pm 0.24 \mathrm{gh}$ \\
& $\mathrm{NL}$ & $1.50 \pm 0.14 \mathrm{ab}$ & $0.48 \pm 0.06 \mathrm{de}$ & $0.68 \pm 0.09 \mathrm{de}$ & $1.08 \pm 0.04 \mathrm{ef}$ & $0.23 \pm 0.04 \mathrm{bc}$ & $0.24 \pm 0.01 \mathrm{bcde}$ & $4.21 \pm 0.42 \mathrm{def}$ \\
& $\mathrm{NM}$ & $1.11 \pm 0.11 \mathrm{~d}$ & $0.46 \pm 0.04 \mathrm{de}$ & $0.95 \pm 0.13 \mathrm{bc}$ & $1.29 \pm 0.02 \mathrm{de}$ & $0.15 \pm 0.15 \mathrm{c}$ & $0.24 \pm 0.02 \mathrm{cde}$ & $4.21 \pm 0.25 \mathrm{def}$ \\
& $\mathrm{NH}$ & $1.12 \pm 0.15 \mathrm{~d}$ & $0.45 \pm 0.12 \mathrm{de}$ & $0.70 \pm 0.08 \mathrm{de}$ & $0.80 \pm 0.17 \mathrm{fg}$ & $0.29 \pm 0.04 \mathrm{bc}$ & $0.22 \pm 0.04 \mathrm{de}$ & $3.59 \pm 0.38 \mathrm{fg}$ \\
$\mathrm{SH}$ & $\mathrm{N} 0$ & $1.07 \pm 0.02 \mathrm{~d}$ & $0.61 \pm 0.02 \mathrm{bcd}$ & $0.21 \pm 0.05 \mathrm{f}$ & $0.14 \pm 0.00 \mathrm{~h}$ & $0.38 \pm 0.09 \mathrm{abc}$ & $0.19 \pm 0.03 \mathrm{e}$ & $2.61 \pm 0.12 \mathrm{~h}$ \\
& $\mathrm{NL}$ & $1.26 \pm 0.08 \mathrm{~cd}$ & $0.56 \pm 0.06 \mathrm{cde}$ & $0.82 \pm 0.12 \mathrm{~cd}$ & $0.27 \pm 0.00 \mathrm{~h}$ & $0.34 \pm 0.03 \mathrm{abc}$ & $0.18 \pm 0.03 \mathrm{e}$ & $3.44 \pm 0.43 \mathrm{fg}$ \\
& $\mathrm{NM}$ & $1.10 \pm 0.21 \mathrm{~d}$ & $0.80 \pm 0.17 \mathrm{~b}$ & $0.73 \pm 0.14 \mathrm{de}$ & $0.32 \pm 0.47 \mathrm{~h}$ & $0.15 \pm 0.12 \mathrm{c}$ & $0.19 \pm 0.05 \mathrm{e}$ & $3.29 \pm 0.12 \mathrm{gh}$ \\
& $\mathrm{NH}$ & $1.11 \pm 0.13 \mathrm{~d}$ & $0.41 \pm 0.09 \mathrm{e}$ & $0.57 \pm 0.17 \mathrm{e}$ & $0.22 \pm 0.05 \mathrm{~h}$ & $0.37 \pm 0.14 \mathrm{abc}$ & $0.19 \pm 0.05 \mathrm{e}$ & $2.87 \pm 0.19 \mathrm{gh}$ \\
\hline
\end{tabular}

Mean values \pm SD are shown. Different letters in the same column indicate significant difference $(P<0.05)$. The symbols represent as in Fig. 2 


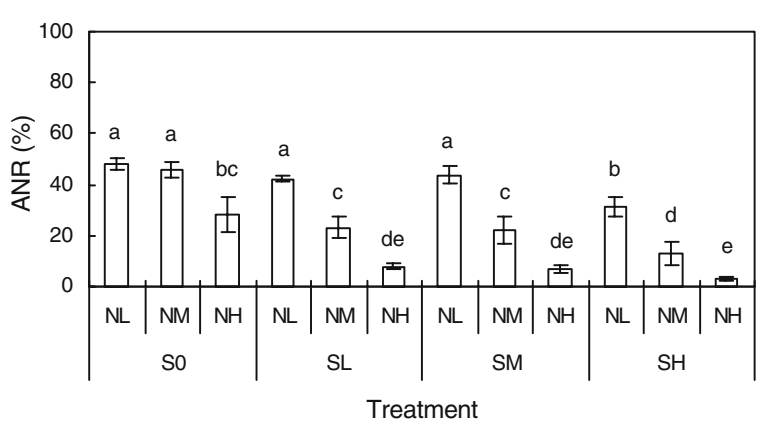

Fig. 4 Effect of soil salinity and $\mathrm{N}$ levels on apparent $\mathrm{N}$ recovery (ANR, \%) of cotton. Bars represent mean \pm SD. Different letters indicate significant difference $(P<0.05)$. The symbols are the same as in Fig. 2

effect of $\mathrm{N}$ application on concentrations of these four ions was limited except for $\mathrm{Ca}$. No $\mathrm{N} \times$ salinity interaction was observed. As the soil salinity level increased, the $\mathrm{K}$ concentration of cotton leaf, stem and bur significantly decreased. Conversely, the $\mathrm{Ca}$, $\mathrm{Na}$ and $\mathrm{Cl}$ concentration of cotton leaf, stem and bur was significantly increased (Table 6). There was no significant difference of $\mathrm{K}, \mathrm{Ca}, \mathrm{Na}$, and $\mathrm{Cl}$ concentrations of seed under different soil salinity treatments. Uptake of $\mathrm{Ca}$ was also affected by the $\mathrm{N}$ application rates. The $\mathrm{Ca}$ concentration of cotton leaf, stem and bur increased as $\mathrm{N}$ application rate increased (data was not presented).

\section{Discussion}

Understanding salinity-fertilizer relationships is of great economic importance and many studies have been conducted to evaluate $\mathrm{N}$ and other nutrients uptake by plants under saline conditions (Papadopulos and Rendig 1983; Feigin 1985; Villa-Castorena et al. 2003; Kutuk et al. 2004). Differences in salt tolerance among plant species have been long recognized; however, the role that salt tolerance plays in causing differences in nutrient uptake at different growth stages is still not fully understood (Pessarakli 1991; Kutuk et al. 2004).

Our experimental results indicated that cotton was more sensitive to salt during the emergence and early growth stages than at later stages. In addition to the vegetative growth, the reproductive growth was also significantly affected by high soil salinity. In our study, under the high soil salinity treatment ( $\mathrm{SH})$, the three-true-leave and the peak blooming stages were delayed about 4 days and 1 week, respectively, in comparison with other treatments. There were fewer bolls per plant and a greater chance of shedding under the high soil salinity treatment $(\mathrm{SH})$, which might be attributed to the nutrient imbalance caused by high soil salinity. Gouia et al. (1994) reported that high salt stress results in slower growth and even death of seeding cotton, lower dry matter accumulation, less

Table 6 Ion concentrations ( $\mathrm{g} \mathrm{kg}^{-1}$ dry weight) in cotton plant parts (leaf, stem, bur, and seed) as affected by soil salinity treatments

\begin{tabular}{llrrrr}
\hline Plant part & Salinity level & K & Na & Ca & Cl \\
\hline Leaf & S0 & $21.33 \pm 2.52 \mathrm{a}$ & $1.04 \pm 0.11 \mathrm{~d}$ & $13.01 \pm 1.20 \mathrm{~d}$ & $10.76 \pm 1.18 \mathrm{~d}$ \\
& SL & $18.89 \pm 1.75 \mathrm{~b}$ & $3.54 \pm 0.33 \mathrm{c}$ & $26.94 \pm 4.62 \mathrm{c}$ & $27.83 \pm 3.05 \mathrm{c}$ \\
& SM & $15.85 \pm 1.13 \mathrm{c}$ & $4.54 \pm 0.34 \mathrm{~b}$ & $33.15 \pm 3.94 \mathrm{~b}$ & $36.89 \pm 4.75 \mathrm{~b}$ \\
& SH & $14.44 \pm 1.37 \mathrm{c}$ & $6.07 \pm 0.42 \mathrm{a}$ & $39.39 \pm 4.99 \mathrm{a}$ & $50.39 \pm 5.92 \mathrm{a}$ \\
Stem & S0 & $19.58 \pm 2.00 \mathrm{a}$ & $1.12 \pm 0.12 \mathrm{~d}$ & $8.22 \pm 1.15 \mathrm{c}$ & $8.02 \pm 0.56 \mathrm{~d}$ \\
& SL & $18.59 \pm 1.76 \mathrm{ab}$ & $2.43 \pm 0.29 \mathrm{c}$ & $9.96 \pm 1.51 \mathrm{~b}$ & $11.87 \pm 1.43 \mathrm{c}$ \\
& SM & $16.92 \pm 2.32 \mathrm{~b}$ & $3.45 \pm 0.32 \mathrm{~b}$ & $11.35 \pm 2.49 \mathrm{~b}$ & $14.66 \pm 1.30 \mathrm{~b}$ \\
& SH & $14.82 \pm 2.21 \mathrm{c}$ & $4.62 \pm 0.32 \mathrm{a}$ & $13.63 \pm 2.83 \mathrm{a}$ & $18.79 \pm 2.34 \mathrm{a}$ \\
& Bur & $32.90 \pm 4.99 \mathrm{a}$ & $0.83 \pm 0.12 \mathrm{~d}$ & $9.02 \pm 1.71 \mathrm{c}$ & $7.68 \pm 0.80 \mathrm{~d}$ \\
& SL & $34.08 \pm 3.17 \mathrm{a}$ & $1.33 \pm 0.15 \mathrm{c}$ & $9.84 \pm 1.68 \mathrm{bc}$ & $10.70 \pm 1.38 \mathrm{c}$ \\
& SM & $31.01 \pm 2.87 \mathrm{a}$ & $1.65 \pm 0.13 \mathrm{~b}$ & $10.85 \pm 1.33 \mathrm{~b}$ & $12.87 \pm 1.24 \mathrm{~b}$ \\
& SH & $27.20 \pm 2.87 \mathrm{~b}$ & $2.28 \pm 0.17 \mathrm{a}$ & $12.69 \pm 1.52 \mathrm{a}$ & $15.83 \pm 1.81 \mathrm{a}$ \\
& S0 & $10.13 \pm 1.04 \mathrm{a}$ & $0.29 \pm 0.12 \mathrm{a}$ & $4.63 \pm 0.59 \mathrm{a}$ & $4.70 \pm 0.44 \mathrm{a}$ \\
& SL & $10.30 \pm 0.99 \mathrm{a}$ & $0.29 \pm 0.06 \mathrm{a}$ & $4.36 \pm 0.58 \mathrm{a}$ & $4.74 \pm 0.48 \mathrm{a}$ \\
& SM & $10.55 \pm 0.79 \mathrm{a}$ & $0.38 \pm 0.14 \mathrm{a}$ & $4.40 \pm 0.66 \mathrm{a}$ & $4.45 \pm 0.63 \mathrm{a}$ \\
& SH & $9.67 \pm 1.11 \mathrm{a}$ & $0.30 \pm 0.10 \mathrm{a}$ & $4.87 \pm 0.57 \mathrm{a}$ & $4.62 \pm 0.63 \mathrm{a}$ \\
\hline
\end{tabular}

Mean values $\pm \mathrm{SD}$ are shown. Different letters in the same column indicate significant difference $(P<0.05)$. The symbols represent as in Fig. 2 


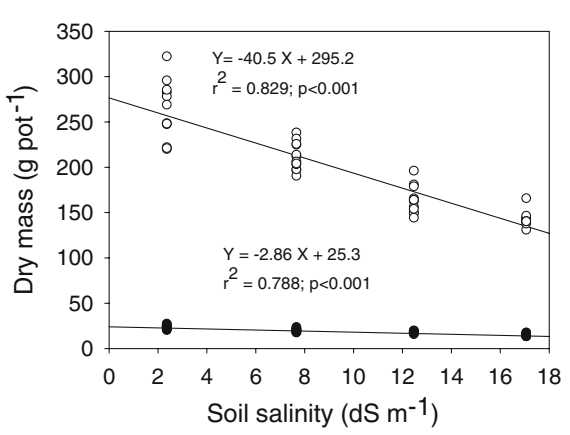

Fig. 5 Dry mass of aboveground and root as a function of soil salinity. The results presented are averages of soil salinity treatments for all $\mathrm{N}$ levels. Lines represent linear correlation

roots, softer and darker leaves, shorter period of blooming, and even death of seedling cotton. Ashraf (2002) showed that under high salt stress, the growth rate of cotton was significantly reduced with less fruiting branches. The appearance of square, flowers and boll was significantly retarded; the blooming stage was shorter and the shedding also increased.

Nevertheless, our experimental results also indicated that the adverse effects of soil salinity on cotton growth could be alleviated by fertilizer application, but over fertilization with $\mathrm{N}$ might contribute to soil salinization and increase the negative effects of soil salinity on plant performance. Villa-Castorena et al. (2003) concluded that over fertilization during the early plant development might contribute to higher soil salinity and decreased pod yield of chile pepper, while salt-stressed chile performed well when they were adequately fertilized. Fertilizer should be applied in amounts that increase with plant need over the growing season. Similarly, Kaya and Higgs (2003) reported that supplementary urea could overcome the effects of high salinity on fruit yield and whole plant biomass in pepper plants.

The effects of soil salinity and $\mathrm{N}$ application on cotton above-ground dry mass were dominated by the soil salinity and could be correlated with root development. The root dry mass also decreased linearly with soil salinity, but at a less pronounced rate (Fig. 5). Reduction in dry matter production with increasing salinity level was noticed by a number of researchers (Abd-Ella and Shalaby 1993; Leidi and Saiz 1997; Qadir and Shams 1997; Ashraf and Ahmad 1999; Basal et al. 2006).

The effect of soil salinity on the root distribution may be closely related to the dynamic salt distribution corresponding to the irrigation and root water uptake (Malash et al. 2008). During an irrigation, the salts around the emitters were transported with water to farther distance and to deeper soil layers. During the intervals between irrigations, the salts may be transported toward the soil surface and roots due to the root water uptake and evaporation. Our measurements showed that the lowest salinity in the soil profile was around the emitter and the highest salinity in the soil profile was found in the top $0-10 \mathrm{~cm}$ soil layer $15-$ $20 \mathrm{~cm}$ from the emitter. The average soil salinity at different depths is illustrated in Fig. 6. Under the low soil salinity treatment of S0, the soil salinity in the $30-50 \mathrm{~cm}$ soil layers was significantly higher than that in the $0-20 \mathrm{~cm}$ soil layers. In contrast, under the high soil salinity treatment $(\mathrm{SH})$, the soil salinity in bottom layers was similar with that in the top 0 $20 \mathrm{~cm}$ layer. During the growing period, cotton may adjust its growth pattern to avoid high salt stresses (Homaee and Schmidhalter 2008). As a result, more roots were distributed in bottom layers under the high soil salinity treatment than under the low soil salinity treatment.

The uptake of nitrate is known to compete with that of Cl, a major ion in saline soil (Xu et al. 2000; Mengel and Kirkby 2001; Abdelgadir et al. 2005). Such an interaction results in diminished $\mathrm{N}$ uptake and decreased plant growth at increased $\mathrm{Cl}$ concentrations. Our experimental results illustrated that at low soil salinity level, increasing the $\mathrm{N}$ application rate could significantly enhance the $\mathrm{N}$ uptake. Under

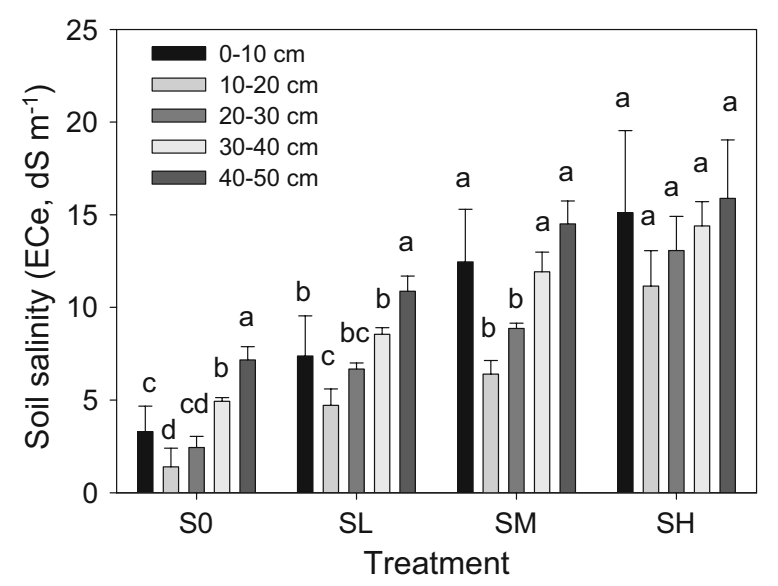

Fig. 6 Soil salinity distribution at different soil depths under salinity treatments. Bars represent mean \pm SD. Different letters indicate significant difference under the same soil salinity treatment $(P<0.05)$. The symbols are the same as in Fig. 2 
moderate soil salinity level, proper use of $\mathrm{N}$ fertilizer was necessary. Over fertilization did not benefit the $\mathrm{N}$ uptake. Under the high soil salinity, salt was the dominated factor governing the cotton growth and $\mathrm{N}$ uptake. The inhibition could not be alleviated by fertilizer application. The findings agree with those observed by Shenker et al. (2003), who demonstrated that increasing the application of $\mathrm{N}$ fertilizer could increase $\mathrm{N}$ uptake, hence the cotton yield. Our study indicated that $\mathrm{N}$ uptake and the cotton yield were not affected by high $\mathrm{N}$ application rate, and the $\mathrm{N}$ uptake and the cotton yield increased as the soil salinity decreased.

The accumulation of $\mathrm{N}$ in different plant parts generally followed a decreasing order of seed $>$ leaf $>$ bur $>$ stem $>$ shed $>$ root, but varied with the soil salinity level (see Table 5). Under the high salinity treatment ( $\mathrm{SH})$, the $\mathrm{N}$ in the cotton seed accounted for about only $8 \%$ of the total $\mathrm{N}$ uptake, while under the other three salinity treatments, it accounted for as much as $31 \%$ of the total $\mathrm{N}$ uptake. Consequently, more $\mathrm{N}$ was accumulated in the leaf and stem parts under high salinity level. The results indicated that there was a nutrient imbalance under the high salinity treatment. The nutrient $(\mathrm{N})$ was mainly used for vegetative growth rather than for reproductive growth.

The concentrations of $\mathrm{Na}, \mathrm{Ca}$, and $\mathrm{Cl}$ in various plant parts of cotton increased as soil salinity increased. The concentrations of these ions among different plant parts followed in a decreasing order: leaf $>$ stem $>$ bur $>$ seed. This kind of distribution pattern of salt ions among different plant tissues was thought to be one of the major salt tolerance mechanisms of cotton (Xin et al. 2005). Leidi and Saiz (1997) demonstrated that the Na concentration in cotton leaves was closely related to plant growth. Fortmeier and Schubert (1995) compared the effect of $\mathrm{NaCl}$ and $\mathrm{Na}_{2} \mathrm{SO}_{4}$ on cotton growth and concluded that the toxicity of salts on cotton was due to $\mathrm{Na}$, not due to $\mathrm{C} 1$, or combination of $\mathrm{Na}$ and $\mathrm{C} 1$. The accumulation of $\mathrm{Na}$ may result in decreased uptake of K, and Ca (Rathert 1983; Saqib et al. 2000; Lee et al. 2007). Our experimental results showed that the $\mathrm{Na}$ concentration of the cotton roots, leaves and stems increased with the soil salinity, the uptake of $\mathrm{K}$ decreased with soil salinity, while the uptake of $\mathrm{Ca}$ increased with soil salinity. The high uptake of Ca may be attributed to the soil salinity treatment in which $1: 1$ of $\mathrm{CaCl}_{2}$ and $\mathrm{NaCl}$ was used. Consequentially, the $\mathrm{Ca}$ in the soil was significantly increased, thus the uptake of $\mathrm{Ca}$ by cotton plant. $\mathrm{K}$ and $\mathrm{Ca}$ play key roles in several physiological processes, while $\mathrm{Na}$ does not function as a macro-nutrient. Thus, the substitution of $\mathrm{K} / \mathrm{Ca}$ by $\mathrm{Na}$ may lead to nutritional imbalances (Gorham and Bridges 1995; Tuna et al. 2007).

\section{Conclusions}

Our experimental results illustrated that both the vegetative growth and the reproductive growth were significantly inhibited by the high soil salinity. At low soil salinity level, increasing the $\mathrm{N}$ application rate could significantly enhance the $\mathrm{N}$ uptake, thus alleviating the adverse effects causing by salinity. Under moderate soil salinity level, proper use of $\mathrm{N}$ fertilizer was necessary. Over fertilization did not benefit $\mathrm{N}$ uptake. Under the high soil salinity, salt was the dominated factor governing the growth of cotton and $\mathrm{N}$ uptake. The inhibition could not be alleviated by fertilizer application.

Open Access This article is distributed under the terms of the Creative Commons Attribution Noncommercial License which permits any noncommercial use, distribution, and reproduction in any medium, provided the original author(s) and source are credited.

\section{References}

Abdelgadir EM, Oka M, Fujiyama H (2005) Characteristics of nitrate uptake by plants under salinity. J Plant Nutr 28:3346 doi:10.1081/PLN-200042156

Abd-Ella MK, Shalaby EE (1993) Cotton response to salinity and different potassium-sodium ratio in irrigation water. $\mathrm{J}$ Agron Crop Sci 170:25-31 doi:10.1111/j.1439-037X.1993. tb01052.x

Alam SM (1994) Nutrient uptake by plants under stress condition. In: Pessarakli M (ed) Handbook of plant and crop stress. Marcel Dekker, New York, pp 227-243

Albassam BA (2001) Effect of nitrate nutrition on growth and nitrogen assimilation of pearl millet exposed to sodium chloride stress. J Plant Nutr 24:1325-1335 doi:10.1081/ PLN-100106984

Ashraf M, Ahmad S (1999) Exploitation of intra-specific genetic variation for improvement of salt $(\mathrm{NaCl})$ tolerance in upland cotton (Gossypium hirsutum L.). Hereditas 131:253-256 doi:10.1111/j.1601-5223.1999.00253.x

Ashraf M (2002) Salt tolerance of cotton: some new advances. Crit Rev Plant Sci 21:1-30 doi:10.1080/0735-260291044160

Basal H, Hemphill JK, Smith CW (2006) Shoot and root characteristics of converted race stocks accesions of 
upland cotton (Gossypium hirsutum L.) grown under salt stress conditions. Am J Plant Path 1(1):99-106

Bowman DC, Devitt DA, Miller WW (2006) The effect of moderate salinity on nitrate leaching from bermudagrass turf: a lysimeter study. Water Air and Soil Poll 175:49-60 doi:10.1007/s11270-006-9110-5

Devitt DA, Morris RL (1990) Effects of irrigation frequency, salinity of irrigation water and soil type on growth and response of bermudagrass. Arid Soil Res Rehabil 5:3546

Endris S, Mohammed MJ (2007) Nutrient acquisition and yield response of barley exposed to salt stress under different levels of potassium nutrition. Int $\mathrm{J}$ Environ Sci Tech 4: 323-330

Feigin A (1985) Fertilization management of crop irrigated with saline water. Plant Soil 89:285-299 doi:10.1007/ BF02182248

Feng ZZ, Wang X, Feng ZW (2005) Soil N and salinity leaching after the autumn irrigation and its impact on groundwater in Hetao irrigation district, China. Agric Water Manage 71:131-143 doi:10.1016/j. agwat. 2004. 07.001

Flores P, Carvajal M, Cerda A, Martinez V (2001) Salinity and ammonium/nitrate interactions on tomato plant development, nutrition, and metabolites. J Plant Nutr 24:15611573 doi:10.1081/PLN-100106021

Fortmeier R, Schubert S (1995) Salt tolerance of maize (Zea mays L.): the role of sodium exclusion. Plant Cell Environ 18:1041-1047 doi:10.1111/j.1365-3040.1995.tb00615.x

Gorham J, Bridges J (1995) Effects of calcium on growth and leaf ion concentrations of Gossypium hirsutum grown in saline hydroponic culture. Plant Soil 176:219-227 doi: 10.1007/BF00011785

Gouia H, Ghorbal MH, Touraine B (1994) Effects of $\mathrm{NaCl}$ on $\mathrm{f}$ lows of $\mathrm{N}$ and mineral ions and on $\mathrm{NO}_{3}{ }^{-}$reduction rate within whole plants of salt-sensitive bean and salt-tolerant cotton. Plant Physiol 105:1409-1418

Homaee M, Schmidhalter U (2008) Water integration by plants root under non-uniform soil salinity. Irrig Sci 27:83-95 doi:10.1007/s00271-008-0123-2

Jacoby B (1994) Mechanisms involved in salt tolerance by plants. In: Pessarakli M (ed) Handbook of plant and crop stress. Marcel Dekker, New York, pp 97-145

Kaya C, Higgs D (2003) Relationship between water use and urea application in salt-stressed pepper plants. J Plant Nutr 26:19-30 doi:10.1081/PLN-120016495

Kutuk C, Cayci G, Heng LK (2004) Effects of increasing salinity and ${ }^{15} \mathrm{~N}$-labelled urea levels on growth, $\mathrm{N}$ uptake, and water use efficiency of young tomato plants. Aust J Soil Res 42:345-351 doi:10.1071/SR02006

Lee G, Duncan RR, Carrow RN (2007) Nutrient uptake responses and inorganic ion contribution to solute potential under salinity stress in halophytic seashore paspalums. Crop Sci 47:2504-2512

Leidi EO, Saiz JF (1997) Is salinity tolerance related to $\mathrm{Na}$ accumulation in upland cotton (Gossypium hirsutum L.) seedlings? Plant Soil 190:67-75 doi:10.1023/A: 1004214825946

Leskys A, Devitt DA, Morris RL, Verchick LS (1999) Response of tall fescue to saline water as influenced by leaching fractions and irrigation uniformity distributions. Agron J 91:409-416
Li F, Liang J, Kang S, Zhang J (2007) Benefits of alternate partial root-zone irrigation on growth, water and nitrogen use efficiencies modified by fertilization and soil water status in maize. Plant Soil 295:279-291 doi:10.1007/ s11104-007-9283-8

Maas EV (1993) Plant growth response to salt stress. In: Lieth $\mathrm{H}$, Masoom AA (eds) Towards the rational use of high salinity tolerant plants, Vol 1. Kluwer Academic Publishers, Dorchrecht, pp 279-291

Maas EV, Grattan SR (1999) Crop yields as affected by salinity. In: Skaggs RW, van Schilfgaarde J (eds) Agricultural Drainage, Agron Monogr 38. ASA, CSSA, SSA, Madison, WI, pp 55-108

Malash NM, Flowers TJ, Ragab R (2008) Effect of irrigation methods, management and salinity of irrigation water on tomato yield, soil moisture and salinity distribution. Irri Sci 26:313-323

Martin B, Thorsteson VR (1988) Stable carbon isotope composition $\left(\delta^{13} \mathrm{C}\right)$, water use efficiency, and biomass productivity of Lycopersion esculentum, Lycopersion pennellii, and F hybrid. Plant Physiol 88:213-217

Mengel K, Kirkby EA (2001) Principles of plant nutrition, 5th edn. Kluwer Academic Publishers, Dordrecht

Mohammad MJ (2004) Squash yield, nutrient content and soil fertility parameters in response to methods of fertilizer application and rates of nitrogen fertigation. Nutr $\mathrm{Cycl}$ Agroecosys 68:99-108 doi:10.1023/B:FRES. 0000019036. $64212.9 \mathrm{c}$

Mohammed MJ, Shibli R, Ajlouni M, Nimri L (1998) Tomato root and shoot responses to salt stress under different levels of phosphorus nutrition. J Plant Nutr 21:1667-1680

Munns R, Tester M (2008) Mechanisms of salinity tolerance. Annu Rev Plant Biol 59:651-668 doi:10.1146/annurev. arplant.59.032607.092911

Oikeh SO, Kling JG, Horst WJ, Chude VO, Carsky RJ (1999) Growth and distribution of maize roots under nitrogen fertilization in plinthite soil. Field Crop Res 62:1-13 doi:10.1016/S0378-4290(98)00169-5

Pessarakli M (1991) Dry matter yield, nitrogen-15 absorption, and water uptake by green bean under sodium chloride stress. Crop Sci 31:1633-1640

Pessarakli M, Tucker TC (1988) Dry matter yield and nitrogen15 uptake by tomatoes under sodium chloride stress. Soil Sci Soc Am J 52:698-700

Papadopulos I, Rendig VV (1983) Interactive effects of salinity and nitrogen on growth and yield of tomato plants. Plant Soil 73:47-57 doi:10.1007/BF02197756

Qadir M, Shams M (1997) Some agronomic and physiological aspects of salt tolerance in cotton (Gossypium hirsutum L.). J Agron Crop Sci 179:101-106 doi:10.1111/j.1439037X.1997.tb00504.X

Qu L, Quroreshi AM, Koike T (2003) Root growth characteristics, biomass and nutrient dynamics of seedlings of two Larch species raised under different fertilization regimes. Plant Soil 255:293-302 doi:10.1023/A:1026159709246

Rathert G (1983) Effects of high salinity stress on mineral and carbohydrate metabolism of two cotton varieties. Plant Soil 73:247-256 doi:10.1007/BF02197720

Ruiz SM, Plana V, Ortuno M (2005) Spatial root distribution of apricot trees in different soil tillage practices. Plant Soil 272:211-221 doi:10.1007/s11104-004-4781-4 
Saqib M, Akhtar J, Qureshi RH, Aslam M, Nawaz S (2000) Effect of salinity and sodicity on growth and ionic relations of different wheat genotypes. Pak J Soil Sci 18: 99-104

Shen D, Shen Q, Liang Y, Liu Y (1994) Effect of nitrogen on the growth and photosynthetic activity of salt-stressed barley. J Plant Nutr 17:787-799

Shenker M, Ben-Gal A, Shani U (2003) Sweet corn response to combined nitrogen and salinity environmental stress. Plant Soil 256:139-147 doi:10.1023/A:1026274015858

Soliman MS, Shalabi HG, Campbell WF (1994) Interaction of salinity, nitrogen, and phosphorus fertilization on wheat. J Plant Nutr 17:1163-1173

Tuna AL, Kayab C, Ashraf M, Altunlu H, Yokas I, Yagmur B (2007) The effects of calcium sulphate on growth, membrane stability and nutrient uptake of tomato plants grown under salt stress. Environ Exp Bot 59:173-178 doi:10.1016/j.envexpbot.2005.12.007

Villa-Castorena M, Ulery AL, Catalan-Valencia EA, Remmenga MD (2003) Salinity and nitrogen rate effects on the growth and yield of chile pepper plants. Soil Sci Soc Am J 67:1781-1789

Wang YG, Xiao DN, Li Y, Li XY (2008) Soil salinity evolution and its relationship with dynamics of groundwater in the oasis of inland river basins: case study from the Fubei region of Xinjiang province, China. Environ Monit Assess 140:291-302 doi:10.1007/s10661-0079867-z

Ward MR, Aslam M, Huffaker RC (1986) Enhancement of nitrate uptake and growth of barley seedlings by calcium under saline conditions. Plant Physiol 80:520-524

Xu G, Magen H, Tarchitzky J, Kafkafi U (2000) Advances in chloride nutrition of plants. Adv Agron 68:97-150

Xin CS, Dong HZ, Tang W, Wen SM (2005) Physiological and molecular mechanisms of salt injury and salt tolerance in cotton. Cotton Sci 17:309-313 (In Chinese)

Zemenchik BA, Albrecht KA (2002) Nitrogen use efficiency and apparent nitrogen recovery of Kentucky bluegrass, smooth bromegrass, and orchardgrass. Agron J 94:421428 